\title{
Opłaty za gospodarowanie odpadami komunalnymi w Warszawie
}

\section{Anna Wieczorek, Maciej Siekierski}

\section{Uchwały Rady m.st. Warszawy dotyczące wysokości opłat za gospodarowanie odpadami komunalnymi}

W dniu 01.04.2021 r. zmieniły się w Warszawie opłaty za gospodarowanie odpadami komunalnymi. To konsekwencja podjętych w dniu 15 października 2020 r. przez Radę m.st. Warszawy uchwał:

- $\operatorname{nr}$ XXXVIII/1199/2020 (zmiana uchwały nr XXIV/671/2019),

- $\quad$ nr XXXVIII/1200/2020 (zmiana uchwały nr XXIV/676/2019),

- $\operatorname{nr}$ XXXVIII/1201/2020 (zmiana uchwały nr XXIV/731/2020).

Pełne nazwy uchwał - patrz materiały źródłowe.

Powyższe uchwały zmieniły obowiązujące od dnia 01.03 .2020 r. opłaty, które w powszechnym odczuciu były drakońska, niesprawiedliwą podwyżką kosztów utrzymania. W szczególności dotknęły jednoosobowe gospodarstwa domowe, które do marca 2020 r. płaciły 10 zł miesięcznie (np. w dzielnicach Ursynów i Ochota) - obecnie 65 zł, a w budynkach jednorodzinnych 94 zł miesięcznie.

Czy kolejna zmiana opłat za gospodarowanie odpadami komunalnymi będzie akceptowana społecznie? W dniu 01.04.2021 r. Polskie Radio (Program I) podało wiadomość, że nowy system został zaskarżony przez spółdzielnie mieszkaniowe. Warto zastanowić się, z czego wynikają nowe opłaty i dlaczego budzą negatywne emocje.

Najistotniejszeznaczenie dla mieszkańców Warszawy ma uchwała nr XXXVIII/1199/ 2020. Dla zachowania precyzji wypowiedzi wybrane fragmenty powyższej uchwały przytoczono w formie cytatów.

Dla „nieruchomości, na której zamieszkują mieszkańcy”:

- _dokonuje się wyboru metody ustalenia opłaty za gospodarowanie odpadami komunalnymi od ilości zużytej wody z danej nieruchomości",

- $\quad$ stawkę opłaty „ustala się w wysokości 12,73 zł za 1 m³ zużytej wody”,

- Średniomiesięczne zużycie wody oblicza się „za okres 6 kolejnych miesięcy przypadających w okresie 12 miesięcy poprzedzających miesiąc, w którym powstał obowiązek złożenia deklaracji o wysokości opłaty za gospodarowanie odpadami komunalnymi" na podstawie wskazania wodomierza lub faktury,

- przy obliczaniu średniomiesięcznego zużycia wody nie uwzględnia się „ilości wody bezpowrotnie zużytej", a to zużycie określa się na podstawie dodatkowego wodomierza, 
- w przypadku nieruchomości niewyposażonej w wodomierz miesięczne zużycie wody ustala się ,jjako iloczyn osób zamieszkujących nieruchomość oraz przeciętnej miesięcznej normy zużycia wody na jednego mieszkańca w gospodarstwie domowym wynoszacej $4 \mathrm{~m}^{3 \prime \prime}$.

Podobnie jak dotychczas, dla nieruchomości, na której nie zamieszkuja mieszkańcy, a powstaja odpady komunalne ustalono opłaty od pojemnika/worka albo ryczałt, przy czym opłaty te podniesiono:

- $\quad$ np. za pojemnik o pojemności 1201 z 5,90 zł do 6,34 zł, a za worek o tej samej pojemności z 16,93 zł do 18,19 zł,

- za domek letniskowy lub inną nieruchomość wykorzystywaną na cele rekreacyjno-wypoczynkowe zmieniono ryczałtową stawkę z 169,30 zł na 181,90 zł za rok.

Dodatkowo, uchwała nr XXXVIII/1200/2020 ustala opłaty dla nieruchomości, na której w części zamieszkują mieszkańcy, a w części jest prowadzona działalność gospodarcza. Uzależnia je również od zużycia wody:

- $\quad$ w części mieszkalnej 12,73 zł za 1 m³ zużytej wody,

- w części niemieszkalnej ,jako iloczyn przeciętnej miesięcznej normy zużycia wody określonej w załączniku do uchwały oraz odpowiedniej wartości określonej tam jednostki odniesienia, właściwej dla danego rodzaju działalności".

Przyjmując, że jeden mieszkaniec zużywa $4 \mathrm{~m}^{3}$ wody miesięcznie, gospodarstwa domowe powinny zapłacić średnio:

- jednoosobowe: 1 osoba x 12,73 zł $/ 1 \mathrm{~m}^{3} \times 4 \mathrm{~m}^{3}=50,92 \mathrm{zł} \mathrm{/} \mathrm{miesięcznie,}$

- dwuosobowe: 2 osoby x 12,73 zł $/ 1 \mathrm{~m}^{3} \times 4 \mathrm{~m}^{3}=101,84 \mathrm{zł} /$ miesięcznie,

- czteroosobowe: 4 osoby x 12,73 zł $/ 1 \mathrm{~m}^{3} \times 4 \mathrm{~m}^{3}=203,68 \mathrm{zł} /$ miesięcznie.

Dotychczas opłaty nie zależały od liczby osób w gospodarstwie domowym, ale od tego, gdzie gospodarstwo domowe mieszkało i wynosiły:

- 94 zł miesięcznie w budynku mieszkalnym jednorodzinnym,

- 65 zł miesięcznie w lokalu położonym w budynku mieszkalnym wielolokalowym.

Z powyższego wynika, że zmiana opłat za gospodarowanie odpadami komunalnymi jest de facto kolejną od 2020 r. dotkliwa podwyżka tych opłat. Rodzina czteroosobowa mieszkająca w budynku jednorodzinnym płaciła miesięcznie 94 zł, a obecnie wydaje się, że zapłaci powyżej 200 zł. Na zmianie opłat być może zyskają jednoosobowe gospodarstwa domowe, np. zamiast 65 zł zapłaca 50,92 zł miesięcznie. Ale to tylko teoria, bo zużycie wody w gospodarstwie jednoosobowym jest większe niż zużycie przypadające na jedną osobę w gospodarstwie kilkuosobowym.

\section{Co musi, a co może Rada m.st. Warszawy}

Ustawa o utrzymaniu czystości i porządku w gminach (ucz) nakłada szereg obowiązków na władze polskich gmin. Gminy mają obowiązek odbierania odpadów komunalnych 
od właścicieli nieruchomości, na których zamieszkują mieszkańcy oraz mogą zorganizować odbieranie odpadów od właścicieli nieruchomości, na których nie zamieszkują mieszkańcy, ale powstają takie odpady [art. $6 \mathrm{c}$ ust. $1 \mathrm{i}$ ust. $2 \mathrm{ucz}$ ].

Powyższa ustawa jest podstawą do podejmowania przez rady gmin uchwał dotyczacych odpadów komunalnych. W przypadku nieruchomości, na której zamieszkują mieszkańcy, należność za gospodarowanie odpadami stanowi iloczyn stawki opłaty oraz:

- liczby mieszkańców zamieszkujących daną nieruchomość,

lub

- ilości zużytej wody w danej nieruchomości,

lub

- powierzchni lokalu mieszkalnego [art. 6j ust. 1 ucz].

Rada gminy może uchwalić również jedną stawkę opłaty liczoną od gospodarstwa domowego [art. 6j ust. 2 ucz].

Stawka opłaty zależy od przeciętnego miesięcznego dochodu rozporządzalnego na 1 osobę. Dochód ten ogłasza corocznie Prezes Głównego Urzędu Statystycznego, wydając stosowne obwieszczenie. W 2020 r. powyższy dochód wynosił 1819 zł. Na tej kwocie oparto opłaty ustalone w uchwałach podjętych przez Radę m.st. Warszawy w październiku $2020 \mathrm{r}$.

Opłata zależna od ilości zużytej wody wynosi nie więcej niż „,0,7\% przeciętnego miesięcznego dochodu rozporządzalnego na 1 osobę ogółem - za $\mathrm{m}^{3}$ zużytej wody" [art. 6j ust. 1 pkt 2 w związku z art. 6k ust. 2a pkt 2 ucz]. W 2020 r. maksymalna opłata oparta na zużyciu wody wyniosła $12,733 \mathrm{zł} / \mathrm{m}^{3}$.

W przypadku „nieruchomości, na której znajduje się domek letniskowy, lub innej nieruchomości wykorzystywanej na cele rekreacyjno-wypoczynkowe, rada gminy uchwala ryczałtową stawkę opłaty za gospodarowanie odpadami komunalnymi nie wyższą niż 10\% przeciętnego miesięcznego dochodu rozporządzalnego na 1 osobę ogółem - za rok" [art. 6c ust. 2c w związku z art. 6j ust. 3b ucz]. W 2020 r. dało to maksymalną kwotę 181,90 zł.

Sumując, Rada m.st. Warszawy miała obowiązek ustalić opłaty za gospodarowanie odpadami komunalnymi dla nieruchomości, na której zamieszkują mieszkańcy oraz dla domków letniskowych.

Rada miała prawo:

- $\quad$ ustalić opłatę dla nieruchomości, na której zamieszkują mieszkańcy, uzależnioną od ilości zużytej wody i zastosować stawkę 12,733 zł / $\mathrm{m}^{3}$,

- dla domków letniskowych oraz innych nieruchomości wykorzystywanych na cele rekreacyjno-wypoczynkowe zastosować stawkę opłaty 181,90 zł za rok.

Powyższe stawki opłat to stawki maksymalne, wynikające z ustawy o utrzymaniu czystości i porządku w gminach. Rada m.st. Warszawy miała prawo je obniżyć, ale z tego prawa nie skorzystała. 


\section{Pokusa wielokrotnego pobierania opłat od tych samych osób fizycznych}

W ustawie o utrzymaniu czystości i porządku w gminach brakuje definicji pojęć, które rzutują na wysokość opłat. Chodzi przede wszystkim o:

- nieruchomość, na której zamieszkują mieszkańcy,

- nieruchomość, na której nie zamieszkują mieszkańcy,

- domek letniskowy.

Definicji tych określeń brakuje również w uchwale nr XXXVIII / 1199/2020, podobnie jak w uchwale nr XXIV/671/2019, co w 2020 r. stwarzało pokusę do wielokrotnego pobierania opłat od tych samych osób fizycznych.

W sytuacji braku powyższych definicji nie pozostaje nic innego, jak posłużyć się powszechnie obowiązującymi przepisami prawa, regulującymi daną dziedziną życia.

Kodeks cywilny stanowi, że:

„Miejscem zamieszkania osoby fizycznej jest miejscowość, w której osoba ta przebywa z zamiarem stałego pobytu." [art. $25 \mathrm{Kc}$ ]

„Można mieć tylko jedno miejsce zamieszkania.” [art. $28 \mathrm{Kc}$ ]

„Nieruchomościami są części powierzchni ziemskiej stanowiące odrębny przedmiot własności (grunty), jak również budynki trwale z gruntem związane lub części takich budynków, jeżeli na mocy przepisów szczególnych stanowią odrębny od gruntu przedmiot własności." [art. $46 \S 1 \mathrm{Kc}$ ]

W świetle powyższego, nieruchomość, na której zamieszkują mieszkańcy, to nieruchomość, w której właściciel czy właściciele lub inne osoby fizyczne przebywają z zamiarem stałego pobytu. Przez analogię - nieruchomość, na której nie zamieszkują mieszkańcy, to nieruchomość, w której właściciel lub inne osoby fizyczne maja prawo przebywać, ale bez zamiaru stałego pobytu - nie deklarują takiego zamiaru.

W polskim systemie prawnym nie znaleziono definicji pojęcia domek letniskowy. Należy podkreślić, że:

- ustawa Prawo budowlane nie zabrania, aby budynek mieszkalny jednorodzinny był traktowany jako domek letniskowy,

- rozporządzenie Rady Ministrów w sprawie Polskiej Klasyfikacji Obiektów Budowlanych stanowi, że budynki mieszkalne jednorodzinne to między innymi domki wypoczynkowe, domy letnie (dział 11, grupa 111, klasa 1110).

Właściciele są obowiązani ponosić opłatę za gospodarowanie odpadami komunalnymi:

- dla nieruchomości, na której zamieszkuja mieszkańcy - za każdy miesiąc, w którym na danej nieruchomości ktoś zamieszkuje [art. 6i ust. 1 pkt 1 ucz],

- dla nieruchomości, na której nie zamieszkuja mieszkańcy - za każdy miesiąc, w którym powstały odpady [art. 6i ust. 1 pkt 2 ucz],

- dla domku letniskowego, czy innej nieruchomości wykorzystywanej na cele rekreacyjno-wypoczynkowe - za rok bez względu na długość okresu korzystania z nieruchomości [art. 6 i ust. 1 pkt 3 ucz].

Podkreślenia wymaga, że stawka 12,73 zł za $1 \mathrm{~m}^{3}$ zużytej wody dotyczy wyłącznie nie- 
ruchomości, na której zamieszkują mieszkańcy, czyli będącej miejscem zamieszkania osoby czy osób fizycznych. Jak już napisano - można mieć tylko jedno miejsce zamieszkania [art. $28 \mathrm{Kc}$. Stawka nie dotyczy nieruchomości będącej własnością osoby fizycznej, która w tej nieruchomości przebywa, ale bez zamiaru stałego pobytu, nawet, jeśli zużywa tam wodę i za nią płaci.

Pozostaje bezspornym, że opłaty za wodę są pobierane na podstawie wskazań licznika. Ta sama osoba fizyczna ma obowiązek płacić za zużytą wodę we wszystkich należących do niej nieruchomościach, a nie tylko w nieruchomości, w której przebywa z zamiarem stałego pobytu. Pod żadnym pozorem zasady tej nie wolno stosować do opłat za gospodarowanie odpadami komunalnymi. Te opłaty nie moga być pobierane kilkakrotnie od tej samej osoby, na podstawie wskazań liczników wody. Osoba fizyczna, która jest właścicielem np. dwóch lokali mieszkalnych za odpady komunalne ma obowiązek płacić tylko od lokalu, w którym deklaruje, że jest jej miejscem zamieszkania.

Zużycie wody w domku letniskowym może być dużo większe niż w lokalu, w którym właściciel tego domku przebywa z zamiarem stałego pobytu. Nie oznacza to, że zamiast ryczałtowej opłaty 181,90 zł za rok ma płacić za odpady 12,73 zł mnożone przez liczbę $\mathrm{m}^{3}$ zużytej wody.

Spory generował będzie również sposób ustala opłat dla nieruchomości w części zamieszkanych, a w części służących działalności gospodarczej. Właściciel budynku jednorodzinnego, który w nim mieszka i pracuje, a ma tylko jeden licznik na wodę, może być narażony na naliczanie opłat za odpady komunalne w taki sposób, który pozwala Władzom Warszawy na ich maksymalizację.

\section{Pokusa „omijania” prawa}

Dla właścicieli budynków mieszkalnych jednorodzinnych najkorzystniejszym wariantem jest „nieruchomość niewyposażona w wodomierz” i deklaracja, że mieszka w niej tylko jedna osoba. Opłata wyniesie 12,73 zł / $1 \mathrm{~m}^{3}$ x $4 \mathrm{~m}^{3}=50,92$ zł / miesięcznie.

Aby to osiagnać, trzeba wykonać własne ujęcie wody. Przy utrzymaniu przez wiele lat opłat za gospodarowanie odpadami uzależnionych od zużycia wody może to być opłacalne, nawet, jeśli na początku ponosi się koszty utworzenia ujęcia. Przedmiotem artykułu nie jest analiza wpływu takich rozwiązań na środowisko, ale ich masowość może być szkodliwa.

\section{Zmiana prawa}

Przy obecnym stanie prawnym, najbardziej akceptowalną społecznie wydaje się opłata uzależniona od liczby osób zamieszkujących daną nieruchomość. Metoda ta będzie sprawiedliwa, jeśli szanuje się przepis, który stanowi, że można mieć tylko jedno miejsce zamieszkania [art. $28 \mathrm{Kc}$ ]. 
Uzależnienie wysokości opłat od ilości zużytej wody powoduje, że najwięcej zapłaca ci, którzy dbaja o higienę. Dziwi premiowanie „brudasów”, zwłaszcza w dobie pandemii, kiedy cały czas namawia się, i słusznie, do mycia rąk.

Odpady komunalne, to wytwór ludzi. Ich ilość nie zależy od zużycia wody. Najprościej byłoby wprowadzić jedną opłatę od każdego człowieka deklarującego miejsce zamieszkania na terenie Polski. Take rozwiązanie zaproponowali autorzy niniejszego artykułu w publikacji p.t. Zmiany w systemie gospodarki odpadami komunalnymi - aspekty prawne i ekonomiczne na przykładzie m.st. Warszawy.

Zlikwidowałoby to spory dotyczace tego:

- czym są nieruchomości, na których zamieszkują mieszkańcy,

- kto gdzie mieszka i ile ma nieruchomości,

- czy budynek mieszkalny jednorodzinny to domek letniskowy,

- $\quad$ kto i ile wody zużywa oraz jak to szacować.

Proponowane rozwiązanie wymaga zmiany ustawy o utrzymaniu czystości i porządku w gminach. Nie leży to w kompetencjach Rady m.st. Warszawy. Ale Radni Stolicy i jej Prezydent mogliby zaapelować do swoich kolegów w Sejmie czy Senacie o wyeliminowanie przepisów dotyczących gospodarowania odpadami, które budzą niezadowolenie społeczne.

\section{Materiały źródłowe}

Wieczorek A., Siekierski M., 2020, Zmiany w systemie gospodarki odpadami komunalnymi-aspekty prawne i ekonomiczne na przykładzie m.st. Warszawy, MAZOWSZE Studia Regionalne, 34, Mazowieckie Biuro Planowania Regionalnego, Warszawa, s. 31-58.

\section{Ustawy}

Kodeks cywilny z dnia 23 kwietnia 1964 r. (tj. z dnia 16 września 2020 r., Dz.U. z 2020 r. poz. 1740 z późn. zm.) w skrócie Kc.

Ustawa z dnia 7 lipca 1994 r. Prawo budowlane (tj. z dnia 7 lipca 2020 r. Dz.U. z 2020 r. poz. 1333 z późn. zm.).

Ustawa z dnia 13 września 1996 r. o utrzymaniu czystości i porządku w gminach (tj. z dnia 22 lipca 2020 r. Dz.U. z 2020 r. poz. 1439 z późn. zm.) w skrócie ucz.

\section{Rozporządzenia}

Rozporządzenie Rady Ministrów z dnia 30 grudnia 1999 r. w sprawie Polskiej Klasyfikacji Obiektów Budowlanych (PKOB) (Dz.U. nr 112, poz. 1316 z późn. zm.). 


\section{Akty prawa miejscowego}

Uchwała nr XXIV/671/2019 Rady m.st. Warszawy z 12 grudnia 2019 r. w sprawie wyboru metody ustalenia opłaty za gospodarowanie odpadami komunalnymi, ustalenia stawki takiej opłaty oraz ustalenia stawki opłaty za pojemnik i worek o określonej pojemności (Dz. Urz. Woj. Mazowieckiego z 16 grudnia 2019 r. poz. 15291),

którą zmieniła

Uchwała nr XXV / 728/2020 Rady m.st. Warszawy z 16 stycznia 2020 r., zmieniająca uchwałe w sprawie wyboru metody ustalenia opłaty za gospodarowanie odpadami komunalnymi, ustalenia stawki takiej opłaty oraz ustalenia stawki opłaty za pojemnik i worek o określonej pojemności (Dz. Urz. Woj. Mazowieckiego z 17 stycznia 2020 r. poz. 870),

które zmieniła

Uchwała nr XXXVIII/1199/2020 Rady m.st. Warszawy z dnia 15 października 2020 r. zmieniająca uchwałe $\mathrm{w}$ sprawie wyboru metody ustalenia opłaty za gospodarowanie odpadami komunalnymi, ustalenia stawki takiej opłaty oraz ustalenia stawki opłaty za pojemnik i worek o określonej pojemności (Dz. Urz. Woj. Mazowieckiego z 23 października 2020 r. poz. 10646).

Uchwała nr XXIV / 676/2019 Rady m.st. Warszawy z 12 grudnia 2019 r. w sprawie ustalenia sposobu obliczania opłaty za gospodarowanie odpadami komunalnymi w przypadku nieruchomości, która w części stanowi nieruchomość, na której zamieszkują mieszkańcy, a w części nieruchomość, na której nie zamieszkują mieszkańcy, a powstają odpady komunalne (Dz. Urz. Woj. Mazowieckiego z 16 grudnia 2019 r. poz. 15293),

którą zmieniła

Uchwała nr XXV / 730/2020 Rady m.st. Warszawy z 16 stycznia 2020 r., zmieniająca uchwałę w sprawie ustalenia sposobu obliczania opłaty za gospodarowanie odpadami komunalnymi w przypadku nieruchomości, która w części stanowi nieruchomość, na której zamieszkują mieszkańcy, a w części nieruchomość, na której nie zamieszkują mieszkańcy, a powstają odpady komunalne (Dz. Urz. Woj. Mazowieckiego z 17 stycznia 2020 r. poz. 872),

które zmieniła

Uchwała nr XXXVIII / 1200/2020 Rady m.st. Warszawy z dnia 15 października 2020 r. zmieniająca uchwałę $\mathrm{w}$ sprawie ustalenia sposobu obliczania opłaty za gospodarowanie odpadami komunalnymi w przypadku nieruchomości, która w części stanowi nieruchomość, na której zamieszkują mieszkańcy, a w części nieruchomość, na której nie zamieszkują mieszkańcy, a powstają odpady komunalne (Dz. Urz. Woj. Mazowieckiego z 23 października 2020 r. poz. 10647). 
Uchwała nr XXV / 731/2020 Rady m.st. Warszawy z 16 stycznia 2020 r. w sprawie określenia wzorów deklaracji o wysokości opłaty za gospodarowanie odpadami komunalnymi oraz warunków i trybu składania deklaracji za pomocą środków komunikacji elektronicznej

(Dz. Urz. Woj. Mazowieckiego z 30 stycznia 2020 r. poz. 1387),

którą zmieniła

Uchwała nr XXXVIII/1201/2020 Rady m.st. Warszawy z dnia 15 października 2020 r. zmieniająca uchwałę w sprawie określenia wzorów deklaracji o wysokości opłaty za gospodarowanie odpadami komunalnymi oraz warunków i trybu składania deklaracji za pomoca środków komunikacji elektronicznej (Dz. Urz. Woj. Mazowieckiego z 23 października 2020 r. poz. 10648).

\section{Obwieszczenie}

Obwieszczenie Prezesa Głównego Urzędu Statystycznego z dnia 31 marca 2020 r. w sprawie przeciętnego miesięcznego dochodu rozporządzalnego na 1 osobę ogółem w 2019 r.

(M.P. z 2020 r. poz. 330).

Anna Wieczorek, Maciej Siekierski - informacje o autorach na stronie 44. 